\title{
Applied Research on the Academy Education for Cultivating Talents in Private Colleges and Universities
}

\author{
Zhang Chi \\ Qi Fang Education Research Institute, Xi’an International University, Xi’an Shaanxi 710077
}

Keywords: academy education; private colleges and universities; cultivation of talent; applied research

\begin{abstract}
As an educational form of organization with a long history, academy education has become an important place for the cultivation of talents, knowledge diffusion, cultural accumulation, and academic research. Academy education plays an active role in cultivating the talents; it is the platform for students' ideological and political education, the key point of cultural and educational construction in campus, the place of broadening the students' scope of knowledge, and the stage for the students to achieve self management. Some private colleges and universities, such as Xi'an International University, have been exploring the academy education seriously, and have achieved some good results.
\end{abstract}

Academy is a special form of educational organization in ancient China. As a unique educational organization in feudal society of China, the academy has played a unique and important role in the history of education. The early academy organized a lot of activities such as collecting books, proofreading books, revising schools, printing books, reading books, and teaching books, etc. By the time of the Song Dynasty, the academy's educational and teaching functions had gradually become complete; it had become the key place of cultivating the talents, cultural accumulation, academic research, and knowledge diffusion. Although the ancient academy has become a part of history, its essence has been lasted forever. The Famous scholar Hu Shi sighed that----“Decline of the ancient academy is really a shame thing of China”. But in recent years, as the prosperous development of the academy, academy education has become one of the hot issues of the academic circle.

\section{Phylogeny of Academy Education}

Academy education is an important and valuable part of the traditional Chinese higher education. Before the Qin Dynasty, Confucius engaged himself in setting up private schools, which can be deemed to be the embryonic form of academy education; the teaching room in the Han Dynasty and the Tang Dynasty can deem to be the precursor of the academy; in the North Song Dynasty, academy came into being. The unique feature of the academy education is that academy is established by the folk scholars without subsidies and authorities of the government, it is quite different from the schools that are established by the government.

In ancient China, the most active school was the private school like academy, when an academy developed quite well, the academy often became official because the government gave it high appraisal and subsidized it. But when the academy become official school, it would be inactive and decline, and would be substituted for the other folk academy. Mr. Tang Junyi named this pheromone "trilogy", i.e., first, a folk academy develops very well; second, the folk academy becomes official academy; third, the official academy declines. In modern society, the traditional academy education still has the indispensable value.

\section{The Functions of Academy Education on Cultivating Talents}

To improve the ideological and political education quality of the university students is not only the urgent need that in order to fit for the changing domestic and overseas situation, but also the 
necessary requirement of all-round development of the higher education; at the some time, it is the important measures for constructing the education that the people is satisfied, and that of following the essential education task---- setting high moral values and cultivating person. Academy education is a kind of platform of ideological and political education, it is helpful for both the students and teachers on ideological and political education, and it is helpful for forming the healthy campus cultures. Establishing an activity room that for Party building of the students, so as to provide a good environment for the students' Party branch to organize all kinds of activities. The academy also can organize various thematic educational activities. For example, before the Chinese traditional holidays, by organizing the various activities which the teachers and students are interested such as thematic lectures, cultural garden tourisms, interesting competitions, so as to develop the socialist core values and Chinese excellent traditional cultures. What's more, to choose some experienced teachers as the tutors of these academies, these tutors can instruct the thematic educational activities of the academies. Every department of a university should have some academic tutors who can combine the features of their majors with the academies closely, actively explore integrating moral education into daily life, and improve the tutors' comprehensive understanding to their students, so as to improve the professional qualities of the students.

College Education can promote students' cultural identity by means of arranging cultural display room, hanging plaques and antithetical couplets, and designing the distinctive cultural identity system; at the some time, the academies can be regarded as an important carrier for inheriting the excellent Chinese traditional culture, carrying forward the spirit that a fish could change to a dragon by constant struggle, and strengthening the identity and cohesion of the academy. Academy education also can focus on the features of the disciplines, by gathering the certain students who learns the related disciplines together in a academy, so as to form the academic cultures with different characteristics, and some brand activities. It is also important to improve students' international vision constantly, to show the students' humanistic spirit, and to highlight social practice by academy education. To build a library in academy is also necessary, in the academies, the students could think about life philosophy in an impractical discussion, invite some specialists and scholars to interpret the classical traditional works by means of some reading activities, and discuss some social hot issues with the students and inherit Chinese excellent traditional culture, so as to cultivate the humanistic spirit of the students and carry forward the campus culture.

In the original students' living quarters, the university should plan an overall layout of the academies reasonably, carefully design the architectural structure, and develop the educational function of these academies. In every academy, it is necessary to build some public functional rooms for reading, organizing activities, so as to improve the intimate relationship between the teachers and students in transferring knowledge, academic accomplishment and personal charisma. The tutors of the academies should solve the problems of the students by means of organizing forum or thematic project and so on, which are helpful for the tutors to actively participate in the associations of the academies and social practice activities, to guide the students in learning, to edification the students in daily life and lead the students in the cultivation of personality, so as to promote the students to lay a solid foundation for their future career life by emphasizing the importance of their studies, to promote the scientific research and innovation by improving the academic ability, and to explore the regular of development by research and consultation.

It is feasible to establish the self management committee and self supervision committee of the students by means of academy education. The self-management committee, focusing on the purpose and spirit of the academies, designs and develops activities of learning, daily life, and culture; it undertakes the operation and management of the public space of the academies. The supervision committee receives and passing on the opinions and needs of the students, issues the bulletin of the academy regularly, and deliberates on the important programs that involve the construction of academies and the public interests. By the implementation of these measures, the daily communication platform of the academy has been established, and then, some public affairs of the academy also can be partly open up to the students, so as to train the students' ability of participating in the actual public life by means of the corresponding training that helps the students 
to participate in the management and decision-making of the academy. The students' organizations play an active role on selecting and engaging the managers and supervisors, and on achieving the self management of the students.

\section{Practices of Academy Education in Xi'an International University}

In the environment of Internet is common and the colleges and universities are opening up, academy model has become a new cultivation model of many famous colleges and universities. In the 9 private colleges or universities in Shaanxi Province, Xijing University and Xi'an International University have taken the lead in the exploration of academy education. Especially, the Xi'an International University has accumulated a lot of experiences in running school by means of academy education, and also has been fruitful in talent training.

Xi'an international University has been innovating the teaching models and exploring the reform directions of private education actively. In resent years, it carries out the new education model of "college \& academy"; at the some time, it had established eight famous academies that are "Angel Academy" of the Medical School, "Kaiyuan Academy" of the Foreign Language School, "Yuhua Dragon Academy" of the School of International Business and Trade, "Soaring Dragon Academy" of Engineering School, "Rain Flower Academy” of School of Liberal Arts, "Action-awareness Merging Academy" of the Business School, "Wisdom Academy" of the Logistics School, and the "Erudition Academy" of the Vocational Education College. These academies are very helpful and effective in the aspects of student management, the second classroom of the students, and the moral education of the students.

The innovative managerial model of students' dormitories has created the atmosphere of "one family" for the students; it fully shows consideration for the students' personal life habits, and lets the students have a sense of belonging to the campus and dormitory. Since the implementation of the managerial system of academy, the students live in the dormitories as if they were at home, they cherish the public facilities and maintain a clear public environment consciously; at the some time, they keep a good relationship between the houseparent and the teachers. Some students said frankly that----"when they went to a different place for studying and left their parents and their familiar cities, it was inevitable there would be differences and homesickness in their hearts, but in the schools and academies, by the considerate care of the teachers who like their parents were everywhere, and then, they slowly adapted to the campus life.

What the academy advocates is a kind of culture, which is trying to cultivate students' humanistic spirit, seeking spirit, innovation spirit and practical ability, and actively exploring a new model of cultivating the talents, a new model that could integrate students' quality education, humanity education and interest education together. The new teaching model has gradually realized the students' cultural cultivation, the complementation of the different majors, and the expansion of their personality; academy encourages the communications between the students with different academic backgrounds, so as to satisfy the students' individualized developmental requirements, and finally to promote the all-round development of students. Taking the academy as the main position, Xi'an International University takes the academies as the "second classroom" of the students, and develops the formative education of interest cultivation, moral education, psychological service, and interpersonal skill improvement in the aspects of studying, interest, life, etc.

The student managerial model of academy advocates the teaching style of "taking students and the moral cultivation as the first" and the studying style of "developing the students' personality and paying attention to their cultivation"; by this way, it strengthens the consciousness of educating people of the teachers, and improves the educational environment and realizes the "Seven Combinations"----combination of college and academies, combination of the "first classroom" and the "second classroom", combination of the life tutor and the study tutor, combination of instructor and houseparent, combination of education and management, combination of teaching and education, combination of service and education----so as to create a "all-staff, whole-process, all-round" education atmosphere, to improve the level of student education and management, and to 
constantly improve the quality of the cultivation of the talents.

Many students whose majors are foreign languages participate in the activities of "Kaiyuan Academy”. Xi'an International University is one of the founders of the international development of the domestic private colleges and universities, its International communication and international cooperation education are far ahead of the other private colleges and universities in China. Some characteristic activities of the academy have received high appraisals of the teachers and students such as Cultural Festival Ceremony Competition, AIDS Propaganda Day, and Encouraging Kindness, etc. The "Flower Rain Academy" of School of Liberal Arts also has organized some wonderful activities that are rich in contents, various in form, and close to the life of the university students, such as the "A war of words" Debate Competition, Calligraphy Experience Day, "Love warming Winter" Public Welfare Photo Exhibition, etc. By these activities of the academy, the academy provides the educational opportunities that are different from the tedious lessons, so that the students' professional education and liberal studies are combined more closely, and at the same time, the students' self-confidence, interpersonal communication ability and cultural tastes are improved. The "Angel Academy" aims at cultivating the students' personalities and developing the students in an all-round way, it organizes and develops non-curriculum education, social practice activities and campus cultural activities so as to promote students' self-management. Its activities such as sweep the graves named "remembering the heroic martyrs and carrying forward the revolutionary spirit", first aid drill named "lighting the fire of life, spreading the rescue light" and so on, were organized in order to promote the love of the world and the warm feelings of the doctors who like angels in the world. The "Qifang Academy" actively explores the new model of modern education of colleges and universities, and devotes itself to the creation of a new model of education with its unique characteristics that is "college \& academy" in Xi'an International University, and expands the traditional "classroom teaching" to "dormitory", "studying association", "MOOC" and so on; in the aspect of teaching content, it changes the past "academic" education, to " moral " education; in the aspect of managerial model, it extends from the traditional "teacher institution " and "instructor institution " to "tutor institution ", so as to achieve the combination of the "first classroom" and the "second classroom", the combination of the "study tutor" and "life tutor", and to achieve "teaching students in accordance with their aptitude".

\section{Conclusion}

The helpful experiences in aspects of teaching and management of Chinese traditional academy education have some certain reference value for today's private colleges and universities. The interaction in academy education is the key method for improving the indifferent relationship between students and teachers in private colleges and universities, and raising the close emotion of them. The flexible teaching materials and the various teaching methods of academy education can improve the lagging situation such as teaching model is simple, teaching materials are tedious, teaching ideologies are old. The profound knowledge and passive enthusiasm of the tutors in academies like a mirror that the teachers of private colleges and universities can reflect on themselves and find out their deficiencies of professional knowledge and teaching attitudes. Academy education plays an active role in the cultivation of talents in private colleges and universities, and it further improves the quality of talent cultivation in private colleges and universities.

\section{Acknowledgements}

Scientific Research Program Funded by Shaanxi Provincial Education Department (Program No. 14JZ042)

\section{References}

[1] Fudan University. The New Cultivation Model that Based on Academy Construction of Fudan 
University[EB/OL], Official Website of Ministry of Education of the People's Republic of China, http://www.moe.edu.cn/jyb_xwfb/s6192/s133/s164/201610/t20161010_284150.html, 2016-10-10.

[2] Xi'an International University. Xi'an International University Carries Out the Academy Student Management Model with Good Effect[EB/OL], Official Website of Education Department of Shaanxi Provincial Government,

[3] http://www.snedu.gov.cn/jynews/gdxx/201410/15/44025.html, 2014-10-15. 